\title{
Alkohol i norsk historie
}

\author{
Ragnar Hauge
}

Statens institutt for alkohol- og narkotikaforskning, Dannevigsveien 10, 0463 Oslo

\section{ALKOHOLBRUK I MIDDELALDEREN}

Den første beskrivelsen av alkoholbruk i Norden stammer fra den romerske historieskriveren Tacitus i boken "Germanien" fra rundt år 100 . Det Germania Tacitus beskriver er landene nord for Rhinen og Donau - hvor Romerrikets grenser gikk - og hvor Svionene var betegnelsen på dem som bebodde den skandinaviske halvøy. I motsetning til romerne drakk germanerne "et brygg av bygg eller hvete som er gått i gjæring, slik at det har fătt noen likhet med vin" (Tacitus 1901-1902:134). Germanernes matvaner var enkle og måteholdne, med "viltvoksende frukter, et stykke viltkjøtt eller tykk melk, uten tilberedning og uten lekkerier fordriver de sulten". Men når det gjaldt drikke var forholdet et annet:

"...overfor tørsten viser de ikke det samme måtehold. Gir man etter for deres drikkelyst og lar dem få så meget som de lyster, vil drikken lettere gjøre det av med dem enn våpenmakt."

Tradisjonen var, ifølge Tacitus, at etter at germanerne hadde stått opp og tatt sitt morgenbad, gikk de til sitt arbeide. Men - legger han til (Tacitus 1901-1902:133134):

"...like så ofte til gilde, alltid væpnede. Å sitte ved drikken dag og natt igjennom har ingen noen skam av. Ofte, som rimelig er mellom berusede, forefaller det kivsmål, og et slikt føres sjelden igjennom med krangel, oftere med drap og sår. Men både utsoning mellom uvenner, ekteskapsforbindelser mellom forskjellige slekter og utsøkelse av høvdinger, endelig også fred og krig, rådslår de ofte om under gjestebud, alt $i$ den tanke at det ikke gis noen anledning hvor sinnet er lettere tilgjengelig for jevne tanker eller bedre lar seg oppildne til store."

Selv om Tacitus i ettertid ikke har vært ansett som noen særlig pålitelig kilde, er gildetradisjonen noe vi finner igjen $\mathrm{i}$ den eldste norske lovgivning fra middelalderen - $\mathrm{i}$ landskapslovene fra rundt år 1000 . Men gildets funksjon var ikke å være et drikkelag. Gildet eller gjestebudet var stedet hvor viktige beslutninger ble truffet. I et samfunn som det gammelnorske hvor skrivekunsten var forbeholdt et lite fåtall, ble beslutninger og avtaler folk imellom ikke nedtegnet, men avtalt muntlig. Slike avtaler måtte skje i vitterlig- het med vitner som kunne stadfeste hva som var besluttet og avtalt, slik at tvil og uenighet om innholdet kunne unngås. Og en av de situasjoner hvor folk som kunne vitne var forsamlet - på Tacitus' som på landskapslovenes tid - var når det ble holdt gjestebud eller gilde. Det var derfor nærliggende å treffe beslutninger og slutte avtaler der. Men i gilder eller gjestebud ble det også drukket øl. De bestemmelser som finnes både om avtaleinngåelse og ølbruk i landskapslovene er derfor i stor grad knyttet sammen.

Gulatingsloven, som trolig er den eldste av landskapslovene og den som er mest fullstendig bevart, fastslår at datidens viktigste avtaleinngåelse - nemlig overdragelse av jord - skulle foregå i "fjølda manna", dvs. der mange menn var samlet, som "kirkestevne, $i$ ølhus og på fullbemannet skip". Å gi sitt barn bort som gjeldstrell måtte skje "på ting eller i ølhus eller på kirkestevne". Også mange andre viktige avtaler ble inngått i gilde eller ølhus - enten det nå gjaldt å ta opp uekte barn i slekten, ekteskapsinngåelse eller frigivelse av treller. I lovgivningen blir de tilstedeværende ofte betegnet som "drikkelagsgjester" eller "ølhusvitner".

At stedet hvor gildet ble holdt - gildehuset eller ølhuset som det ble kalt - var likestilt med kirken og tinget er ikke så overraskende. Alt var steder hvor mange var samlet som kunne vitne om det som skjedde. I det gammelnorske samfunn hadde derfor ølhus og gilde med sin øldrikking en sosialt rituell funksjon. I endel tilfelle hadde de også en religiøst rituell funksjon. Gulatings loven pålegger bøndene å slå seg sammen og brygge øl som skulle drikkes i fellesskap før helgemess og til jul, og ølet skulle signes "til takk frå Krist og Sankta Maria til godt år og fred".

At alkoholbruken i visse tilfelle kunne ta overhånd - slik også Tacitus beskriver det - og lede til slagsmål og voldsbruk var trolig ikke så helt sjelden. Taranger og Gurstad (1916:6) sier da også om ølbruken under gildene: "At de blir drukne, forutsettes som en selvfølge". Landskapslovene gir også regler både om drap og slagsmål i ølhus og gilde. Sammenkomstens rituelle preg gjorde at sakene ifølge loven kunne pådømmes direkte i ølhuset, og rettsboten skulle settes til det dobbelte av det vanlige.

Selv om trolig drukkenskap i gildene ikke var så sjelden - og at slagsmål og drap kunne forekomme - 
er det grunn til å tro at fordi ølbruken og den drukkenskap som fulgte med, skjedde i en rituell sammenheng under sosial kontroll fra de tilstedeværende, ble de verste utglidninger holdt i sjakk. Kanskje var heller ikke ølbruken så omfattende som man ofte kan få inntrykk av i senere beskrivelser av de gamle nordmenns liv. Det har vært beregnet at omfanget av kornproduksjonen lå på rundt $150 \mathrm{~kg} \mathrm{pr}$. innbygger på 1300-tallet (Lunden 1976) - og det er ingen grunn til å tro at det lå særlig høyere tidligere. Dette betød trolig at for folk flest var øl en luksusartikkel. Det kornet de hadde til rådighet kunne anvendes bedre til grøt, flatbrød og såkorn enn å maltes og brukes til ølbrygging. Kanskje er dette bakgrunnen for at lovene påla bøndene plikt til å brygge $ø 1$ til visse høytider - fordi de ellers ville foretrukket å bruke kornet på annen måte. Og at det til tross for påbudet åpenbart var noen som forsøkte å unndra seg dette, fremgår av lovene som truet med strenge straffer for å unnlate å brygge øl til høytidene.

At landskapslovene bare omtaler øl og ikke andre alkoholdrikker, er ikke tilfeldig. Riktignok hadde man også mjød. Men fordi mjød ble fremstilt av honning og honning var en kostbar vare - var denne drikken forbeholdt overklassen. Enkelte hadde nok også stiftet bekjentskap med vin på utferdene til sørligere land men vin var trolig enda sjeldnere i bruk. Blant folk flest var øl det man drakk av alkoholholdige drikker, og utenom gildene måtte nok flertallet nøye seg med å drikke vann, surmelk eller andre simple drikker.

Den rituelle bruken av øl synes imidlertid gradvis å ha gått ut av bruk i den senere del middelalderen. Magnus lagabøters lovgivning som avløste landskapslovene på slutten av 1200-tallet, tyder på dette. I Magnus lagabøters landslov - som regulerte forholdene på landsbygda - omtales riktignok fremdeles gildene, men de synes ikke lenger å ha noe rituelt preg. Gilde brukes nærmest synonymt med gjestebud i sin alminnelighet. Man finner også de første lovbestemmelser som setter begrensninger for øldrikking og beruselse. I avskrifter av Frostatingsloven fra midten av 1200-tallet var det forbud mot å føre øl til tinget, og dette forbudet ble videreført i Magnus lagabøters landslov. Landsloven anbefaler også at man istedet for å holde overdådige gravøl eller sjeleøl bør gi større almisser for de dødes sjeler, og det settes forbud mot gravøl hvor folk drikker seg fulle, fordi det ved slike anledninger "ofte er inntruffet store ulykker og manndrap på grunn av altfor meget fylleri."

I Magnus lagabøters bylov gis det i byanordningen regler for hvordan vekterne skal forholde seg overfor dem som var drukne - det var bestemt at de skulle vise dem på rett vei, og at det å ta noe fra dem skulle bedømmes som tyveri. At slike bestemmelser ble ansett for nødvendige, synes å peke i retning av at døddrukne folk i gatene var noe som forekom ikke så helt sjelden. Men samtidig tyder de på at det ikke ble ansett som særlig klanderverdig å være overstadig beruset - lovbestemmelsene er satt til vern og ikke til kontroll av dem som ikke kunne ta vare på seg selv.

Selv om drikking og beruselse ikke lenger var del av rituelle sammenkomster, synes derfor alkoholbruken ikke å ha blitt ansett for noe sosialt problem av betydning i middelalderen. Dette fremgår også av andre kilder. I Håvamål i den eldre Edda advares det riktignok mot "ovdrikk", som i Mortensson-Egnunds oversettelse lyder (Håvamål 1986: vers 11 og 12):

"Betre byrdi du ber kje i bakken enn mannevit mykje. Med låkare niste du legg kje i veg enn ovdrykke av $ø l$. - Ikkje så godt som godt dei seier er øl for manneætt. Di meir du drikk di mindre vit du i hausen hava."

Men "ovdrikk" av øl er bare en av de mange ting det advares mot i Håvamål - et par vers senere fordømmes også "ovetaren". I Kongespeilet (1947:83-84) fra 1200-tallet advarer en far sin sønn mot de mange fristelser han kan bli utsatt for - bl.a. mot drikkelag og å drikke seg full. Men advarselen er holdt i forsiktige former - drikkelag godtas i "kongens hus eller i sømmelig lag", og advarselen mot å drikke seg drukken står i kapitlet om hirdmenns seder. Den er først og fremst begrunnet $i$ at den overklasse som Kongespeilet rettet seg mot kunne bli kalt til rettssaker eller tilsyn eller bli stilt overfor vanskelige saker, og dersom han da var drukken "da er han ikke før til noenting".

Kong Sverre gikk riktignok sterkere ut i den kjente talen mot drukkenskap som han holdt i Bergen i 1186 (Sverres saga 1986:152-153). Bakgrunnen for talen var ifølge sagaen at tyskerne hadde ført med seg store mengder vin til byen. Dette førte til mye drikking og ufred - blant annet at en av birkebeinerne ble så vettløs av drikk at han hoppet på sjøen og druknet, mens en annen sprang utfor bryggen i kongsgården med samme resultat. Ett av drikkegildene utviklet seg til et alvorlig slagsmål mellom en del av bymennene og Sverres menn. Men talen var mindre rettet mot alkoholen enn mot de tyske handelsmenn som bragte slike unødvendige varer til byen i bytte mot smør og skrei, som landet selv hadde bruk for.

\section{OVERGANGEN TIL DEN NYE TID}

At alkoholbruk i liten utstrekning synes å ha blitt opplevd som noe sosialt problem i middelalderen kan trolig tilbakeføres til mange ulike forhold. Trolig var bruk av øl relativt sjelden blant folk flest. Det er også grunn til å tro at det rituelle preget og den uformelle kontrollen ved drikkesitusjonene førte til å forebygge utglidninger. Og den universelle kirke og presteskapet fungerte trolig som en effektiv kontrollør av folks liv og levnet.

Fra 1500-tallet synes forholdene å endre seg. Beskrivelser av tøylesløs alkoholbruk blir mer og mer vanlig innenfor alle samfunnslag, og ikke minst 
innenfor overklassen. I en beskrivelse gitt av kong Christian 4's livlege heter det at "de fleste danske, især av adelen, er overordentlig hengivne til drikk og kan tilbringe natt og dag med å tømme begere" (Troels-Lund 1940:183). Ikke minst gjaldt dette ved selskapelighet, som det ga seg mange anledninger til. Bryllupsfeiringer var ett eksempel (Troels-Lund 1940:510):

"En fransk gjest ved et adelig bryllup i København i 1629 fikk således følgende inntrykk av festen: "I de tre dagene bryllupet varte, drakk gjestene uten stans. Det er alltid en tyve-tredve stykker som holder det gående, mens de som er fulle, sover ut rusen et par timer, og så tar de til å drikke på ny med friskt mot. Prinsen blev drukken fem eller seks ganger og stattholderen også; tirsdag da jeg så ham sist, var han full ennå." En annen franskmann som var gjest ved prins Christians bryllup i 1634, forteller: "Maten var utmerket efter dansk smak, men den smakte ikke oss." Etter at folk var gått fra bordet og dansen var begynt "holdt de like fullt ved med å drikke for hverandre. En av de fornemste gjestene, som jeg ikke skal nevne navnet på, trengte sig plutselig gjennem selskapet, men han greide ikke å komme til døren før han måtte kaste opp. Vi franskmenn syntes den gangen at det var nytt og lite tiltalende. Men efter at vi hadde fart rundt blandt folk i Norden i to år, syntes vi ikke det var så rart lenger."

En indikasjon på at overdådig alkoholkonsum var utbredt blant høyere sosiale lag også utenfor adelens rekker, gir en gjennomgåelse av pådømte drapssaker i 1500-tallets Norge (Sandnes 1990). Disse drapene var svært ofte et resultat av krangler og uoverensstemmelser som fant sted i drikkelag, hvor man trakk kniv eller brukte andre tilgjengelige våpen overfor den man var uenig med. Selv om alle samfunnslag var representert i disse drapssakene, kom en uforholdmessig stor del av drapsmennene fra de øvre sosiale lag. På grunnlag av drapssaker omtalt i Absalon Beyers dagbok fra Bergen - som på den tid var en by på ca. 6000 innbyggere - uttaler Sandnes (1990:70):

\footnotetext{
"Ja, det mest slående er kanskje at så mange av drapsmennene kommer fra de øvre lag i samfunnet. I 1569 stakk lagmannen Christopher Nilssøn i Stavanger ihjel Peter, sønn av den kjente borgermester i Trondheim, Adrian Falkener. Drapet skjedde på Bergenhus. To år seinere, i 1571, stakk en stesønn av Adrian Falkener og et par andre Christian Sefrinssøn fra Jylland til døde. Samme år stakk en "hoffmann", Henrik Holst, ned og drepte en borger. En skipper fra Wismar stakk ihjel en båtsmann etter øldrikking og "perlemente", og det femte og siste drapet dette året gjorde Lars skytter da han stakk Jacob skriver i brystet "saa at lungen hekk ut"."
}

Noe tilsvarende finner Sandnes også i drapssaker fra andre deler av landet. Drap syntes å være særlig utbredt der man fant selveiende bønder som hadde anledning og råd til å delta i drikkelag. I bygder hvor folk flest var leilendinger og husmenn var det mer sjelden. Telemark - sammen med Agder - var et område hvor alkoholbruk og drap var utbredt. Telemarksbøndenes tvilsomme levnet ble også fremhevet av Peder Claussøn Friis i "Norges beskrivelse" fra slutten av 1500-tallet. Innbyggerne der var ifølge Friis "onde, ugudelige, hårde, ville og opprørske folk" (Friis 1881:300):

"Dette len er på alle sider omgitt av store, øde fjell, bortsett fra den del som vender mot sjøen ut til Skiene. Et vidt og folkerikt len hvor det bor rike folk. Og de må vel være rike - og kunne vært enda rikere dersom de ikke med deres svære, umåtelige drikk og gjestebud, og som der gjerne følger med, store brødepenger for hugg og slag, mord og manndrap, hor og andre synder som de bedriver, ikke hadde forspilt så meget."

Den tilsynelatende endring i alkoholbruken og de økte sosiale problemer som den nye tid bragte med seg, kan skyldes mange forhold. Det kan henge sammen med at drukkenskap faktisk ble mer vanlig enn tidligere - og en mulig årsak til dette kan isåfall være at brennevinet etterhvert fikk innpass fra siste halvdel av 1500 -tallet. En annen forklaring kan være at den nye tid førte til samfunnsendringer i form av økt mobilitet og fremvekst av byer og handel som førte til en svekkelse av den gamle samfunnsorden. Som det har blitt uttrykt (Steen 1935:150):

\footnotetext{
"Det 16. århundre er preget av et dypt moralsk forfall. En stund ser det ut som om hele den gamle stats- og samfunnsbygning skal ramle sammen. Retten spottes, tallet på lovbrudd stiger, uhemmet hengir folk sig til fråtseri i mat og drikke og seksuelle utskeielser; byene lignes med Sodoma og Gomora, syndens arnesteder."
}

At drukkenskap syntes å vokse frem som et problem etter middelalderens slutt kan også henge sammen med at den nye, reformerte kirke ikke var istand til å øve den samme kontroll over folk som pavekirken i middelalderens samfunn. Under katolisismen hadde det vært kirken selv som øvet justis over menighetslemmene. Kirken hadde særlig i senmiddelalderen fått utstrakt selvstyre når det gjaldt såkalte åndelige saker - som etterhvert kom til å omfatte svært mange livsområder. Kirken ga sine egne lover og hadde domsmyndighet overfor dem som overtrådte kristenretten - og ikke minst gjennom prestenes mer uformelle kirketukt sørget man for at folk utviste en kristelig livsførsel. Ved reformasjonen falt dette selvstyret bort - kongen ble kirkens overhode og verdslige lover avløste kristenretten. Også når det gjaldt utøvelsen av kirketukt ble det gjennom lovgivningen satt grenser for presteskapet.

Blant den reformerte prestestand syntes drukkenskap heller ikke å være noe fremmed. Dette gir biskop Jens Nilssøns visitasbøker fra Oslo og Hamar stift på slutten av 1500 -tallet et innblikk i. I visitasbøkene gis det detaljerte beskrivelser av reiseruten og av biskopens mange gjøremål underveis, derunder hans 
refselse av prestene for deres drukkenskap. Under en visitas til Østfold og Båhuslen i 1594 beskrives det f.eks. fra Uddevalla hvordan biskopen kalte "herr Peder opp på kammeret og vennlig påminte ham om at han skulle vokte seg for drikk og slagsmål, som sies om ham" (Nilssøn 1885:143-4). I Tegneby talte han Niels Christenssøn "skarpelig til for hans drukkenskap som han hadde hørt om ham" (Nilssøn 1885: 202-3). Kapellanen i Tegneby - som i likhet med sin sogneprest var drikkfeldig - ble formant om å "vokte seg for drikk og ta vare på sitt kall og embete, hvorpå herr Seffren rakte bispen sin hånd, så tilga bispen ham det han hadde imot ham for hans drukkenskap" (Nilssøn 1885:216-217). Herr Peder i Mykleby og herr Nils ble gitt en alvorlig formaning om "at de skulle flittelig ta vare på sitt embete og vokte seg for drukkenskap og alt ondt som dermed følger" (Nilssøn 1885:210). Slike enkeltbeskrivelser trenger riktignok ikke å være - og er sannsynligvis heller ikke - representative for prestestanden. Da som nå var det trolig avvikene fra det normale som fanget oppmerksomhet og ble omtalt. Men at såpass mange geistlige trengte å bli formant av biskopen for sin drukkenskap på en og samme visitas, tyder likevel på at det ikke var så helt sjelden at slikt forekom.

Kongen i egenskap av kirkens overhode og den som skulle opprettholde moral og orden, søkte gjennom et utall av lover å regulere folks atferd. I denne lovgivningen sto motarbeidelse av alkoholbruk i forbindelse med religiøse høytider og begivenheter sentralt. For det var særlig om helligdagene - når folk hadde fri - at alkoholbruk var utbredt, og selskapelighet hvor alkohol ble servert var i stor grad knyttet til kirkelige begivenheter som barnedåp, bryllup og begravelse.

For å forhindre at folk satte seg til å drikke fremfor å oppsøke gudstjenesten, ble det i helligdagslovgivningen satt regler for salg og skjenkning i kirketiden. Allerede kort etter reformasjonen ble det bestemt at alkoholdrikker ikke skulle kunne tappes eller omsettes før middag på helligdager. Dette ble gjentatt i Koldinghusresessen av 13. desember 1558 med den begrunnelse at "ingen skal holdes fra prekenen eller fra å besøke annen gudstjeneste i kirken". Forbudet ble åpenbart ikke alltid etterlevd, og det måtte derfor gjentas og innskjerpes opp gjennom tidene, som i den norske kirkeordinansen av 2. juli 1607 som satte forbud mot å omsette øl ved prestegården. Begrunnelsen var at det i Norge "storlig er blitt misbrukt med prestenes forsømmelse og mangens forargelse med å holde krambod for å utsette øl i eller straks ved prestegårdene". Dette var trolig et betimelig forbud. Prestegårdene lå vanligvis i tilknytning til kirken, og i helgene og høytidene samlet folk seg fra fjern og nær på kirkebakken før gudstjenesten - og noen av dem som kom langveis fra var ofte kommet dagen før. Når man nå var sammen med naboer og kjentfolk og fri fra sine daglige gjøremål, var det utvilsomt fristende å drikke, dersom drikkevarer var tilgjengelige. Dessuten var visstnok heller ikke alle prester helt uinteresserte i kroene og ølbodene nær kirkestedene, som kunne bli en viss attåtnæring for dem. Som Steen (1935:153) uttrykker det:

"Ofte ble presten gjestgiver, ikke nettopp for å tjene på bondens tørst, men fordi prestegården lå ved allfarveien, og opprettelsen av gjestgiveriene sto i forbindelse med den økede ferdsel."

Det var imidlertid ikke bare på kirkebakken eller på skjenkesteder at alkoholbruk på helligdagene kunne finne sted. Også private feiringer kunne virke forstyrrende inn. I en resess av 31 . mai 1586 ble det bestemt at $\mathrm{i}$ adelsbrylluper skulle brudeparet være i kirken senest klokken elleve, fordi "det undertiden har skjedd at gudstjenesten er oppholdt til klokken tolv og endog til klokken ett på dagen, med den følge at folk kommer drukne og ubesindige til kirken ikke uten forargelse og til Guds store fortørnelse." Og i en lang rekke bestemmelser - både for adelsskapet, geistligheten og for alminnelige bønder og byboere - ble det gitt bestemmelser som regulerte alkoholbruken ved større familiebegivenheter.

Likvaken var også en anledning til utskeielser. Under katolisismen var regelen at den døde skulle i jorden etter en natts likvake, hvor bønn og salmesang var de viktigste ingredienser. Men etter reformasjonen våknet de gamle tradisjoner til live. Mat og drikke måtte til under likvaken, som kunne vare i dagesvis. En utlending beskrev det på følgende måte: "Når noen dør, så gråter og jamrer de ikke, men ber, spiser, drikker og danser rundt omkring liket." (Troels-Lund 1941:479). For å forhindre slike tilstander forbød kirkeordinansen av 1607 flere netters likvake "i hvilken der ikke finnes annet enn gilde, gjestebud, drukkenskap, lek og raseri slik som hos hedningene, som aldri akter dødens kristelige betenkende". Det var også forbud mot å være drukken for dem som skulle føre lik til kirken, fordi "de undertiden mister dette eller lar det falle slemt."

Hvor effektive disse forbudene var vet vi lite om. Men de ble nok ofte overtrådt, og i stadig nye lover ble forbudene og bestemmelsene understreket og innskjerpet. Knappe 20 år etter kirkeordin ansen finner man det f.eks. nødvendig i en forordning av 1. mai 1624 på nytt å presisere at likvakedrikking skal være avskaffet, og at det heller ikke var tillatt å drikke i begravelse etter at liket er nedsatt i jorden, fordi "slik hedensk fylleri skal den avdøde til ære, helt være avskaffet". Men de gamle skikker var trolig ikke så lett å utrydde. Ihvertfall kan Ludvig Holberg fortelle fra sin barndom i Bergen på slutten av 1600-tallet (Troels-Lund 1941:481):

\footnotetext{
"Hverken mat eller drikke ble spart i sørgestuer, men allting gas ut i overflod for å fornøye de inviterte venner, slik at man med langt større lyst og fornøyelse da bivånet våke- og sørgestuer enn
} 
nåomstunder brylluper. Jeg erindrer meg i min barndom hvilken glede det var for meg og andre når vi fikk vite at et av våre naboers barn var død; for da fulgte mange gode, fete dager."

Også mer verdslige begivenheter samlet folk - og fristet dem til å feire samværet. Tingsamlingene var en slik begivenhet. Den gamle bestemmelsen fra Magnus lagabøters landslov som satte forbud mot å omsette øl eller drikke på tinget var fremdeles gjeldende rett. Men for å sikre seg at folk var edru på tinget ble det dessuten i et åpent brev av 16. februar 1593 bestemt at tinget skulle settes klokken syv om morgenen om sommeren og klokken åtte om vinteren, for at ikke de "av våre undersåtter, av adel så vel som av borgere og bønder, som søker landstinget, er drukne og fulle". Og et åpent brev av 30. juni 1593 innskjerpet forbudet mot å selge og tappe "sterke drikker" på steder der det skulle holdes ting, fordi "mange, når de kommer inn på tinget, da er de fulle".

\section{MERKANTILISMENS ALKOHOLPOLITIKK}

Det som hadde særpreget alkohollovgivningen på 1500-tallet og første del av 1600-tallet var at den særlig satte begrensninger når det gjaldt alkoholbruk i bestemte situasjoner - på helligdager, før gudstjenesten, på tinget eller kirkebakken - eller i mer eller mindre religiøst pregede sammenkomster som bryllup og begravelser. Lovgivningen tok i stor grad sikte på det som i moderne språkbruk benevnes som punktavhold eller kanskje heller punktmoderasjon. Derimot tok lovgivningen i mindre grad sikte på å begrense bruken og tilgjengeligheten av alkohol generelt - som i våre dager er det viktigste alkoholpolitiske virkemiddel. Men fra siste del av 1600-tallet synes det å skje en endring - ved at lovgivningen i større grad blir rettet inn mot dette.

Kanskje kan denne endringen tilbakeføres til de økonomiske endringer som fant sted. Mens 1500tallet og første del av 1600-tallet var preget av oppgangstider som også kom bøndene - som utgjorde den alt overveiende del av befolkningen - til del, ble forholdene etterhvert forverret. Leieavgiftene på leilendingenes gårder ble skrudd opp og bøndene ble også pålagt andre skatter og avgifter, bl.a. å bekoste soldater. Fiskehandelen og særlig trelasthandelen som tidligere hadde gitt gode inntekter til bøndene ble overtatt av storborgerskapet i byene. De som ikke hadde noen gård å overta - enten som selveier eller leilending - måtte ta arbeide som gårdsarbeider, rydde en husmannsplass eller søke seg jobb i byene. Og ikke så få måtte vende seg til fattigkassen eller slå seg igjennom som tiggere, omstreifere og løsgjengere på evig flukt fra fogdene.

Denne utviklingen var delvis et resultat av det nye økonomiske system - merkantilismen - som fra 1600tallet for alvor fikk fotfeste i Danmark-Norge. Ifølge merkantilismen besto et lands rikdommer av den reserve man kunne bygge opp av gull og sølv. Dette kunne oppnås ved på den ene side å begrense importen og gjøre landet mest mulig selvforsynt når det gjaldt nødvendige forbruksvarer, samtidig som man støttet eksportnæringene som skaffet rikdommer til landet. For at statskassen ikke skulle bli berøvet inntekter i form av toll og avgifter, var bl.a. for kontrollens skyld handel en enerett for handelsborgerne i kjøpstedene - både når det gjaldt eksport og import og innenfor den enkelte kjøpstads omland.

Det nye økonomiske system hadde trolig konsekvenser både for alkoholbruken og kontrollen med alkohol. Økningen i handelsvirksomheten førte til at også alkohol ble en mer alminnelig handelsvare fra siste del av 1600-tallet. Mens det tradisjonelt hadde bydd på problemer å få bøndene langs allfarveien til å opprette vertshus og kroer, endret situasjonen seg etterhvert. Alkoholomsetning ble åpenbart en innbringende næringsvei for mange av dem som hadde fått sitt næringsgrunnlag innskrenket, og salgsog skjenkesteder av ulik art fra hytter og fjeleboder til mer standsmessige krohus ble satt opp. Som Steen (1935:153) uttrykker det:

\footnotetext{
"Drukkenskapen som lenge hadde herjet byene, bredte seg nå over bygdene også sammen med brennevinet, aqua vitæ, "livets vann" som på denne tid trengte inn. Det ble også lettere for bøndene å skaffe seg sterk drikk ved opprettelsen av gjestgiverier i hundretall langs veiene og leden."
}

Det er riktignok liten grunn til å tro at alkoholbruken var økende. Beskrivelsene av nordmenns overdådige alkoholbruk synes å bli sjeldnere fra slutten av 1600tallet, selv om man kanskje ikke kan legge så mye i dette. Men det er sannsynlig at forarmingen av store deler av den vanlige befolkning førte til at de hadde mindre til overs som de kunne bruke til alkohol enn tidligere, også fordi det var dyrere å kjøpe på skjenkestedene enn å lage det selv. Dessuten fikk pietismen gjennomslag fra begynnelsen av 1700tallet, noe som trolig ga seg utslag i redusert alkoholkonsum, særlig i forbindelse med helligdager og religiøse begivenheter.

Fra myndighetenes side var det imidlertid viktig å få både alkoholbruken og omsetningen under kontroll, fordi den på mange måter var i strid med den økonomiske politikk som man forsøkte å gjennomføre. Dette kunne skje ved å begrense importen av unødvendige varer som alkohol, å forhindre at kornet som en viktig vare ble ødet ved å benyttes til øl og brennevin og å sikre byborgernes enerett til og dermed myndighetenes kontroll over handelen. Dessuten var det viktig å sørge for at bøndenes arbeidskraft ble nyttet til landets beste, og ikke ble redusert som følge av drukkenskap. En kristelig livsførsel krevde dessuten - nå som tidligere - edruelighet på helligdagene. De mange hensyn som krevde at man fikk alkoholen 
under kontroll illustreres av en forordning rettet mot ulovlig krohold på landet av 30. april 1734, som er begrunnet i å "motvirke kjøpstadhandelens forringelse, konsumsjonsinntektenes avgang, sabbattens overtredelse og landmannens drukkenskap."

Ut fra disse ulike hensyn ble det gitt et utall av lover som regulerte import, omsetning og bruk av alkohol. Det åpne brevet av 30. juni 1593 som innskjerpet forbudet mot å selge alkohol på tinget satte også forbud mot å bygge krohus og hytter på landsbygda, og ved en forordning av 1 . mai 1618 ble all utskjenkning på landsbygda forbudt - annet enn fra de kroer som var forordnet langs allfarveien. Og disse kunne bare skjenke de veifarende, og ikke bøndene. Begrunnelsen var "den store skade og uskikkelighet som kroer og ølsalg på landet forårsaker $i$ det den alminnelige mann med dette ikke bare avholdes fra sitt arbeide og sin næring, men også får tilfelle til å forbruke sin formue der." For ytterligere å forhindre alkoholbruk blant bøndene ble det samtidig bestemt at det på landsbygda ikke skulle være lov å holde gilde mer enn tre ganger i løpet av året - fordi de "forårsaker akkurat den samme uorden og skade som kroene." Disse bestemmelsene ble gjentatt i en rekke lover opp gjennom 1600- og 1700-tallet.

Gjennom luksuslovgivningen søkte man også å begrense alkoholbruken - og i særdeleshet bruken av importerte alkoholvarer. Luksuslovgivningen var riktignok ikke primært rettet mot alkohol - alkohol var bare en av de former for unødig sløseri og forbruk av landets ressurser man søkte å forhindre. Et eksempel på de vidtgående bestemmelser som ble gitt i luksuslovgivningen gir bok 2, kap. 8 i Den store resess av 27. februar 1643 med overskriften "Om brylluper, barsler, begravelser og annen unyttig bekostning." I loven bestemmes det bl.a. at i adelige brylluper kunne bruden bare bære tre smykker, det var forbudt å sy perler, gull og sølv på brudekjolen og å dekke brudesengen med fløyel. Bryllupet skulle ikke vare mer enn to dager, det var ikke tillatt å servere konfekt, bankett eller bakverk, og i svennesalen var all servering forbudt annet enn av dansk øl. For de øvrige befolkningslag var det satt strengere rammer for bryllupsfeiringer. Ved andre høytideligheter var den overdådighet man kunne tillate seg vesentlig mer begrenset - ved barsler som tidligere hadde vært omgitt med stor festivitas ble det f.eks. helt forbudt å bespise og bedrikke gjester. I tiden som fulgte ble disse bestemmelsene med visse mellomrom innskjerpet i nye lover, samtidig som det ble satt enda sterkere begrensninger for den overdådighet man kunne tillate seg.

For å begrense brennevinsbruken fikk man fra slutten av 1600-tallet bestemmelser med sikte på å regulere produksjon og omsetning av brennevin. Tildels var disse bestemmelsene mer bestemt av ernæringssituasjonen enn av alkoholpolitiske hensyn. Råvarene ved brennevinsproduksjonen var korn, og når misvekst og uår truet landet var det behov for å bruke kornet til bedre formål. Det kom derfor ofte kongelige forordninger som forbød eller innskrenket adgangen til å brenne, slik at kornet i stedet kunne benyttes som matkorn. Fra høsten 1699 til høsten 1700 var det således brenningsforbud, og det samme gjaldt fra sommeren 1709 til høsten 1711. I det sønnenfjellske Norge var det likeledes brenningsforbud fra høsten 1740 til høsten 1742 og fra sommeren 1756. Hvor utbredt brenningen var fremgår av at ved forbudet i 1740 ble 5657 brennevinskjeler forseglet bare i Akershus (Steen 1932:188).

Den merkantilistisk pregede regulering av alkoholen nådde et klimaks ved en forordning av 8 . mars 1757 hvor det ble innført et generelt forbud mot all brennevinsbrenning i Norge. Men forordningen gikk langt videre - den er i realiteten den første generelle alkohollov i Norge. Omsetning av alkohol utenfor byene ble forbudt for alle andre enn de som hadde spesiell bevilling til å drive skjenkesteder. Slik bevilling skulle bare gis dersom stedet lå langt fra nærmeste by eller var nødvendig for de veifarende. Skjenkning måtte bare skje til reisende, mens folk fra distriktet kunne kjøpe drikkevarer der og ta det med seg for å drikke det hjemme. Det ble også satt begrensninger i bruken av alkohol i selskapelighet på landet. Det var forbudt å ta med seg, servere eller drikke annet enn øl i "noe vertskap eller gilde, som bryllup, barsel, begravelse eller annen forsamling". For byenes vedkommende ble det ikke satt noen spesielle begrensninger for skjenkningen overfor dem som var bosatt der. Men tilreisende fra landet var det forbudt å skjenke annet enn øl. Det ble også satt forbud mot import av brennevin, bortsett fra det som kom fra Danmark, hertugdømmene eller dansk Vestindia.

\section{ALKOHOLBRUK OG LIBERALISME}

Mot slutten av 1700-tallet ble merkantilismen avløst av opplysningstidens økonomiske liberalisme. De sterke reguleringer som handel og næringsliv var underlagt fra statens side skulle bortfalle, og istedet skulle markedskreftene styre utviklingen både innenfor det enkelte land og mellom landene. Under påvirkning av den økonomiske liberalisme falt fra slutten av 1700-tallet luksuslovgivningens bestemmelser bort, brennevinsbrenning ble på nytt tillatt for næringsdrivende i byene og importrestriksjonene ble lempet.

Blant Eidsvollsmennene og de senere stortingsmenn sto liberalistiske synspunkter sentralt. Ved en lov av 1. juli 1816 fikk bøndene tilbake sin rett til å brenne brennevin til husholdsbruk, og også til å selge sine produkter. Dette førte til at brennerivirksomheten vokste frem til å bli landets viktigste industrielle virksomhet i de første årene etter 1814. Dette skyldtes ikke minst at poteten - som hadde blitt introdusert i Norge på 1700-tallet - viste seg å være et godt og 
billig råstoff til produksjonen. Også retten til å omsette brennevin ble liberalisert. Enhver som drev handel - handelsborgere og høkere i byene og landhandlerne på landsbygda - kunne selge brennevin. Utskjenking - og derunder salg - kunne også uten spesiell bevilling foretas av dem som drev vertshus eller gjestgiveri.

Liberaliseringen når det gjaldt brennevin førte til en sterk økning i forbruket. Selv om det ikke finnes noen sikre statistiske opplysninger, ble forbruket av brennevin i Norge beregnet til å være ca. 7 liter pr. innbygger i 1833. Dette representerte en meget drastisk økning fra siste del av dansketiden - hvor forbruket ble beregnet til ca. 1,5 liter i 1814. Beruselse og fyll syntes å høre til dagens orden (Keilhau 1931:50):

\footnotetext{
"Nye skikker kom opp. Daglønnere og tjenestefolk krevde å få kontraktsmessig rett til bestemte drammer i tillegg til kosten, og husbonden gikk som oftest med på det, for det falt billigere enn lønnspålegg og holdt drengestuen i godt humør. I de egentlige bondehushold trengte også de daglige drammer inn. De fikk forskjellige kjelenavn. Der var "morgendram" til frokost, "appetittsup" til middag, "knorrel" til eftasverd og "sovedram" til kveldsverd. Dessuten stilte mange en flaske ved sengekanten for å kunne ta seg en nattdram eller to."
}

Alkoholbruken og drukkenskapen som syntes å gripe om seg - ikke minst blant de lavere sosiale lag som husmenn og tjenestefolk og den nye gruppe av arbeidere som den industrielle revolusjon hadde skapt - ble av arbeidsgiverne og "de kondisjonerte" sett på som et onde. Og etterhvert hevet det seg røster for på ny å få til en begrensning av bruken av brennevin. Motstanden mot brennevinsondet - som det ble betegnet av dem som så med uro på hvordan bruken av brennevin hadde bredt seg - vokste seg gradvis sterkere. Fra slutten av 1830-årene oppsto en mer organisert motstand gjennom måteholdsforeningene. En lang rekke av datidens ledende personligheter - både innenfor embetsverk, politikk og kulturliv - var aktive i bevegelsen, noe som gjorde at de fikk stor gjennomslagskraft i den alkoholpolitiske debatt. Og dermed var veien åpnet for å gjennomføre tiltak mot brennevinet.

De første forsøk på begrensninger skjedde gjennom innføring av forskjellige avgifter. I 1820- og 1830-årene kom det avgifter og avgiftsforhøyelser på brennevinsbrenningen, og regler som begrenset produsentenes adgang til å selge produktene. For å foreta utskjenking av brennevin måtte man ha spesiell skjenkebevilling fra formannskapet, og skjenkestedene fikk ikke lenger lov til å selge brennevin som gjestene kunne ta med seg hjem. I 1845 ble også salg av brennevin fra handlende underlagt bevillingsplikt, og de måtte betale en avgift for dette som gjorde at mange av de mindre salgsstedene for brennevin forsvant, ikke minst utover i landdistriktene.
Parallelt med denne mer restriktive holdning skjedde trolig en gradvis nedgang i brennevinsbruken. Men nedgangen skyldtes antakelig like mye endringene i holdningen til brennevinsbruk, som de restriksjoner som ble innført. Selv om man mangler sikre data om alkoholforbruket er det antatt at topp-punktet ble nådd en eller annen gang på slutten av 1830-årene - altså før restriksjonene var kommet for alvor (Fuglum 1972). Den mest nærliggende fortolkning er at de samme holdninger som ledet til måteholdsbevegelsens fremvekst fra slutten av 1830-årene, også førte til motstand mot brennevinsbruk og brennevinsbrenning. Et eksempel på denne holdningsendringen gir situasjonen i Trondheim (Mykland 1955: 283):

\footnotetext{
"Tidligere hadde brennevinet blitt ansett som en nødvendighetsartikkel på linje med korn og salt; nå var det mange som betraktet det som en "etende kreftbyll" og "tuseners forbannelse". Da haugianeren Erich Willum begynte sitt brenneri i 1815 var det ingen som fant noe merkelig $i$ at han, en leser, ville ernære seg ved brennevinsbrenning. Da H. Moe i 1840-årene reiste et nytt brenneri, vakte det forbitrelse hos mange: "I mitt nabolag har brennevinsbrenner Moe av sine syndepenger oppført et stort, vakkert hus" skrev pastor Fredrik Storm til sin venn rektor Bugge i 1840, "og brenner Lysholm har bygget et overmåte stort, nytt helvete."
}

Den tidligere måteholdsbevegelsen ble etter midten av 1800-tallet avløst av totalavholdsbevegelsen, som gradvis vokste frem til en meget innflytelsesrik gruppering, ikke minst politisk (Fuglum 1972). Mens måteholdsbevegelsen hadde vært rettet mot brennevinet - og holdt ølet og vinen utenfor - gikk avholdsbevegelsen mot all bruk av alkohol. Og i motsetning til måteholdsbevegelsen, som i særlig grad hadde omfattet de noe høyere samfunnslag, fikk avholdsbevegelsen gjennomslag i de brede lag av befolkningen. Innenfor den fremvoksende arbeiderklassen ble edruelighet sett på som en forutsetning for å bedre sine kår, og drukkenskap som noe som holdt folk nede i armod og elendighet.

I kampen for edruelighet blant arbeidsfolk var brennevinet fremdeles hovedfienden. Ved en lovendring av 3. mai 1871 hadde det blitt åpnet adgang til å gi bevilling til omsetning av brennevin til et spesielt opprettet selskap. Ideen var hentet fra Sverige hvor det var blitt kjent under navnet "Gøteborgsystemet", og besto $\mathrm{i}$ at $\mathrm{i}$ stedet for å gi bevilling til private næringsdrivende ble den gitt til et "bolag". Eierne av "bolaget" skulle bare ha en viss forrentning av sine penger, for øvrig skulle overskuddet fra omsetningen gå til forskjellige gode formål - i Gøteborg til arbeiderklassens beste. På denne måten ville man få fjernet profittmotivet fra omsetningen, samtidig som man fikk både salget, og ikke minst skjenkingen, inn i ordnede og kontrollerte former. Ifølge loven av 1871 skulle bevillingen på tilsvarende måte kunne gis til et såkalt samlag - som det ble betegnet som i Norge. 
Overskuddet fra virksomheten skulle gå til allmennyttige formål i kommunen, og kunne dermed gi kjærkomne bidrag til slunkne kommunekasser.

Samlagsordningen ble av avholdsbevegelsen - og andre - sett på som et formålstjenlig middel til å begrense brennevinsbruken. Og systemet ble raskt tatt opp av mange kommuner utover i landet. Ved utgangen av 1879 var samlagsordningen innført i de fleste byer i landet hvor brenne vin ble omsatt, selv om enkelte byer - som Oslo og Trondheim - sto utenfor ordningen. Avholdsbevegelsen gikk imidlertid inn for at samlag burde bli en obligatorisk ordning. Og de gikk videre - og krevde at befolkningen selv gjennom folkeavstemning måtte få avgjøre hvorvidt de ville ha brennevinssalg i sin kommune eller ikke.

Avholdsbevegelsens syn slo også igjennom. Ved en ny brennevinslov av 24. juni 1894 ble ordningene med samlag som eneste omsetningssystem og folkeavstemning innført både når det gjaldt salg og skjenking av brennevin. For å forhindre at kommunen skulle få for store økonomiske interesser i salget ble det, i motsetning til tidligere, bestemt at kommunen bare skulle få 15 prosent av overskuddet. Av det resterende skulle 20 prosent gå til samlaget til fordeling blant avholdsforeninger og andre og de resterende 65 prosent til staten. Begrunnelsen for å frata kommunen overskuddet var at mange kommuner hadde benyttet overskuddet til alminnelige kommunale formål, og derigjennom hadde skjelet mer til det å skaffe inntekter enn til å begrense omsetningen. Da den nye loven av 1894 trådte i kraft var det opprettet brennevinssamlag i 51 av de daværende 58 norske kjøpsteder og ladesteder. I avstemningene som fant sted i de følgende år sto motstanderne av brennevinssalg sterkest, og antallet byer hvor brennevin kunne selges var i 1899 redusert til 27 og i 1916 til 13.

Men også bruk av andre former for alkohol ble sett på som et problem. Dette gjaldt ikke minst etter introduksjonen av det fabrikklagde, undergjærete ølet - bayerølet - på midten av 1800-tallet. I motsetning til det tidligere overgjærede ølet var bayerølet både sterkere og mer holdbart. Og det ble fra ulike deler av landet rapportert at det nye ølet førte til misbruk. Også når det gjaldt vin kunne man peke på et visst misbruk. Særlig gjaldt dette den såkalte "brennevinsvinen" på 1850-tallet - og senere "laddevinen" på 1890-tallet - en sterkt oppspritet vin som ble populær i mange kretser. Avholdsbevegelsen tok til orde for at også øl og vin burde underlegges samlag og spørsmålet om omsetning avgjøres ved folkeavstemninger i kommunene, men dette fikk ikke gjennomslag. Riktignok ble det i 1870-årene åpnet adgang til å legge omsetningen av øl og vin under et samlag, men i praksis ble det bare opprettet slike samlag i et fătall kommuner. Men fordi salg og skjenking av øl og vin var underlagt kommunale bevillinger, hadde den enkelte kommune likevel i stor grad adgang til å regulere omsetningen slik de måtte ønske.
Til tross for at den økonomiske liberalisme sto nærmest urokket gjennom hele 1800-tallet, gjaldt denne ikke for alkoholomsetningen - ikke minst gjennom innflytelsen fra måteholdsbevegelsen og den senere avholdsbevegelse. Produksjon og omsetning av alkohol ble omgjerdet av strenge restriksjoner. Og denne utviklingen fortsatte også inn i 1900-tallet.

I forbindelse med forsyningssituasjonen under første verdenskrig ble importen av varer vanskeliggjort, og man måtte i stadig større grad bli selvberget. $\AA$ bruke korn og poteter til å lage alkohol, når store deler av befolkningen ikke hadde tilstrekkelig med mat, måtte fortone seg som meningsløst. Etter et par kortvarige, midlertidige forbudsperioder besluttet derfor regjeringen sommeren 1917 på grunnlag av en generell fullmaktslov å forby brennevin, hetvin og øl. Forutsetningen var at disse forbudene skulle oppheves når krigen var over og forsyningssituasjonen på nytt ble normal. Ved fredsslutningen i 1918 syntes imidlertid forbudet å ha fungert godt - alkoholkonsumet var sunket til et minimum, fyll og andre sosiale problemer knyttet til alkoholbruk var redusert og befolkningen hadde lojalt avfunnet seg med forbudet. På dette grunnlag syntes det naturlig å gjøre forbudet permanent. Men i så fall måtte det ha støtte i folkemeningen, og det ble besluttet å forelegge spørsmålet for folket gjennom en folkeavstemning. Det midlertidige forbudet mot brennevin og hetvin ble opprettholdt inntil avstemningen fant sted 1. oktober 1919 - mens derimot omsetningen av øl ble frigitt. Ved avstemningen ble forbudet mot brennevin og hetvin vedtatt med stort flertall.

Selv om det var forbud i Norge var vi imidlertid gjennom handelsavtaler med Spania, Portugal og Frankrike tvunget til å importere store kvanta både av brennevin og hetvin for å få avsetning for norsk fisk. Disse varene kunne ikke selges til andre land fordi avtalene forbød videre eksport - de måtte følgelig lagres eller destrueres. I 1922 ble derfor A/S Vinmonopolet opprettet, med oppgave å importere og lagre det brennevin og den hetvin som Norge ifølge handelsavtalene var tvunget til å avta. Dessuten ble det gitt anledning til å selge svakvin, som ikke var omfattet av forbudet.

Da brennevinsforbudet ble nedstemt ved en ny folkeavstemning i 1926, fikk Vinmonopolet også adgang til å omsette brennevin og hetvin - først ved siden av samlagene, men senere som enerett. Det kunne bare gis bevilling til salg og skjenking av brennevin i kjøpsteder med over 4000 innbyggere, dersom et flertall gikk inn for dette ved folkeavstemning. I den første avstemningsperioden 1929-1934 ble det $i 15$ byer gitt bevilling til omsetning av brennevin, og tallet var i 1940 økt til 17. Vin kunne selges i de kommuner der kommunestyret ga bevilling - også landkommuner. I 1940 var det opprettet vinutsalg i 2 herredskommuner og 12 kjøpsteder og ladesteder i tillegg til dem som hadde brennevinsomsetning. 


\section{FORHOLDENE I DAG}

Nåtiden er ikke tema for denne artikkelen. Men skal vi kort peke på endringene siden midten av århundredet er det liberaliseringen i forholdet til alkohol som slår en i øynene. I den første etterkrigstid frem til rundt 1960 var riktignok alkoholpolitikken i hovedtrekk den samme som i mellomkrigstiden. Men fra da av satte liberaliseringen inn - en liberalisering som etterhvert forsterket seg. Prinsippet om at det bare skulle selges brennevin i bykommuner ble opphevet $\mathrm{i}$ 1967, og at det skal være opp til befolkningen selv gjennom folkeavstemning å avgjøre spørsmålet om salg og skjenkning ble opphevet i 1989. Men liberaliseringen skyldes ikke først og fremst endringene i lovgivningen - lovendringene var mer et resultat av endringene i liberal retning $\mathrm{i}$ befolkningen.

Mens Norge frem til 1960-årene var et land hvor vin og brennevin bare var tilgjengelig i de større byer - og selv ikke alltid der - og hvor det bare i et fåtall kommuner var anledning til å kjøpe eller bli skjenket $ø l$, har dette endret seg totalt. I dag finnes det knapt en kommune i landet hvor ikke øl kan kjøpes eller skjenkes, og i svært mange av dem finnes det også skjenkesteder hvor man kan få vin og brennevin. I 1991 fikk Sogn og Fjordane - som det siste fylke i landet - vinmonopolutsalg, og svært mange byer og større tettsteder har slike utsalg. Og selv om utsalg ikke finnes i kommunen, er for storparten av landets befolkning et utsalg i rimelig nærhet.

\section{REFERANSER}

Beyer, A.P. (1963): Dagbok 1552-1572 og Oration om mester Geble. Utgitt ved R. Iversen. Universitetsforlaget, Oslo.

Friis, P. C. (1881): Norriges Bescriffuelse. I Friis, P. C.: Samlede Skrifter. Utgitt ved Gustav Storm. Den norske historiske forening, Kristiania.

Fuglum, P. (1972): Kampen om alkoholen i Norge 1816-1904. Universitetsforlaget, Oslo.

Gulatingslovi (1969) (Umsett av K. Robberstad). Det norske samlaget, Oslo.

Håvamål (1986) (Omsett av I. Mortensson-Egnund). Det norske samlaget, Oslo.

Kirkeordinansen av 1607 (Den norske) (1985). Faksimileutgave (som også inneholder Forordning om ekteskapssaker av 1582). Den rettshistoriske kommisjon, Oslo.

Kongespeilet (1947) (Oversatt av A. W. Brøgger). H. Aschehoug \& Co., Oslo.

Magnus lagabøters landslov (1915) (Oversatt av A. Taranger). Eget forlag, Kristiania.

Magnus lagabøters bylov (1751-1752). I H. Paus: Samling af gamle norske love. 2 bind. Kongelige universitets bogtrykker, Kjøbenhavn.

Mykland, K.: Fra Søgaden til Strandgaten. 1807-1880. Trondheim bys historie. F. Bruns bokhandels forlag, Trondheim 1955.

Nilssøn, J. (1885): Visitasbøger og reiseoptegnelser 1574-1597. Utgitt ved Y. Nielsen. A.W. Brøggers Bogtrykkeri, Kristiania.

Næss, H. E. (1981): Trolldomsprosessene i Norge. Privat utgivelse, Stavanger.

Sandnes, J. (1990): Kniven, ølet og aeren. Universitetsforlaget, Oslo.

Schou, J.H.: Alfabetisk Register over de Kongelige Forordninger og Aabne Breve, samt andre trykte Forordninger som fra Aar 1670 af ere udkomne. København 1777-1815.

Secher, V. A. (1887-1918): Corpus constitutionum Danice. Forordninger, recesser og andre kongelige breve Danmarks lovgivning vedkommende 1558-1660. Bind 1-6. Rudolf Klein (bind 1) og G. E. C. Gad (bind 2-6), København.

Steen, S. (1932): Det norske folks liv og historie. Tidsrummet 1720 til omkring 1770. H. Aschehoug \& Co, Oslo.

Steen, S. (1935): Det norske folks liv og historie. Tidsrummet fra omkring 1500 til omkring 1600. H. Aschehoug \& Co, Oslo.

Sverres saga og En tale mot biskopene (1986) (Oversatt av A. Holtsmark). Aschehoug, Oslo.

Tacitus, K. (1901-02): Agricola - Germanien (Oversatt av H. H. Lefolii). Selskabet for historiske kildeskrifters oversættelse, København.

Taranger, A. og H. Gurstad (1916): Den norske alkohollovgivnings historiske utvikling. Bilag 2 , nr. 16 til Ot. prp. nr. 43, 1916: Om forandring i lov om salg og skjænkning av brændevin, øl, vin, fruktvin og mjød av 17. mai 1904. Sosialdepartementet, Oslo.

Troels-Lund, T. (1940): Daglig liv i Norden i det sekstende århundre. II. Femte bok: Mat og drikke. Gyldendal, Oslo.

Troels-Lund, T. (1941): Daglig liv i Norden i det sekstende århundre. IV. Fjortende bok: Død og gravferd. Gyldendal, Oslo. 